\title{
Kebijakan Hutang Pada Perusahaan Manufaktur Yang Terdaftar Di Bursa Efek Indonesia
}

\author{
Aries Veronica \\ Fakultas Ekonomi, Universitas Tamansiswa, ariesveronica78@gmail.com
}

\begin{abstract}
ABSTRAK
Penelitian ini bertujuan untuk mengetahui dan menganalisis pengaruh risiko bisnis, kebijakan dividen, pertumbuhan penjualan, pertumbuhan perusahaan dan tangibilitas terhadap kebijakan utang pada perusahaan manufaktur yang terdaftar di Bursa Efek Indonesia. Penelitian ini menggunakan 28 sampel perusahaan manufaktur yang terdaftar di Bursa Efek Indonesia untuk periode 2013-2017 dengan 152 pengamatan total. Hipotesis diuji menggunakan regresi linier berganda untuk menguji pengaruh risiko bisnis, kebijakan dividen, pertumbuhan penjualan, pertumbuhan perusahaan dan tangibilitas terhadap kebijakan utang. Hasil penelitian menunjukkan bahwa terdapat pengaruh simultan Risiko Bisnis, Kebijakan Dividen, Pertumbuhan Penjualan, Pertumbuhan Perusahaan dan Tangibilitas terhadap Kebijakan Hutang. Sedangkan hasil penelitian secara parsial menunjukkan bahwa Risiko Bisnis, Kebijakan Hutang, Pertumbuhan Pertumbuhan Penjualan Perusahaan tidak memiliki pengaruh terhadap Kebijakan Hutang, sedangkan Tangibilitas memiliki pengaruh signifikan terhadap Kebijakan Hutang.
\end{abstract}

Kata kunci: Kebijakan Hutang, Risiko Bisnis, Kebijakan Dividen, Pertumbuhan Penjualan, Pertumbuhan Perusahaan, Tangibilitas

\begin{abstract}
This study aims to determine and analyze the effect of business risk, dividend policy, sales growth, company growth and tangibility of debt policy in manufacturing companies listed on the Indonesia Stock Exchange. This study uses 28 samples of manufacturing companies listed on the Indonesia Stock Exchange for the period 2013-2017 with 152 total observations. The hypothesis is tested using multiple linear regression to test the effect of business risk, dividend policy, sales growth, company growth and tangibility to debt policy. The results showed that there was a simultaneous influence of Business Risk, Dividend Policy, Sales Growth, Company Growth and Tangibility on Debt Policy. Whereas the research results partially show that Business Risk, Debt Policy, Growth in Corporate Sales Growth has no influence on the Debt Policy, while Tangibility has a significant effect on the Debt Policy.
\end{abstract}

Keywords: Debt Policy, Business Risk, Dividend Policy, Sales Growth, Company Growth, Tangibility

\section{A. PENDAHULUAN}

Hutang berpengaruh penting pada perusahaan karena selain sebagai sumber pendanaan ekspansi, hutang merupakan mekanisme yang dapat digunakan untuk mengurangi konflik keagenan (agency conflict). Konflik keagenan berhubungan dengan tujuan utama perusahaan. Menurut Mahendra et al. (2012) Perusahaan yang telah go public memiliki tujuan yang hampir sama yaitu mrncapai keuntungan maksimal dan memakmurkan pemilik perusahaan atau para pemilik saham. Dalam menjalankan perusahaan, pemegang saham melimpahkan kepada pihak lain yaitu manajer sehingga terjadi pemisahan antara fungsi kepemilikan dan fungsi pengelolaan. 
Pengambilan keputusan yang dilaksanakan oleh manajer sering bertentangan dengan tujuan utama perusahaan.Pertentangan kepentingan tersebut disebut dengan konflik keagenan. Konflik keagenan dapat juga terjadi karena manajer memiliki informasi yang lebih baik tentang prospek perusahaan dibandingkan dengan yang dimiliki oleh pemegang saham atau disebut dengan asymetricinformation (Brigham dan Houston, 2011). Konflik keagenan menimbulkan biayakeagenan (agency cost) untuk mensejajarkan kepentingan-kepentingan manajer dan pemegang saham yang dapat dikurangi dengan penggunaan hutang.

Menurut Brigham dan Houston (2011), salah satu alternatif untuk mengurangi kelebihan arus kas adalah dengan hutang yang lebih besar dengan harapan persyaratan pelayanan hutang akan memaksa manajer menjadi lebih disiplin. Manajer akan memiliki kemungkinan kecil untuk melakukan pengeluaran yang sia-sia jika perusahaan memiliki persyaratan pelayanan hutang dalam jumlah besar. Dalam menentukan kebijakan hutang, ada beberapa faktor yang dipertimbangkan oleh perusahaan pada umumnya antara lain risiko bisnis, kebijakan dividen, pertumbuhan penjualan, pertumbuhan perusahaan, dan tangibility.

Menurut Brigham dan Houston (2011) risiko bisnis adalah tingkat risiko interen dalam operasi perusahaan jika tidak menggunakan hutang. Risiko bisnis adalah ketidakpastian yang dihadapi perusahaan dalam menjalankan kegiatan bisnisnya. Risiko bisnis dapat meningkat ketika perusahaan menggunakan hutang yang tinggi untuk memenuhi kebutuhan pendanaannya. Risiko timbul seiring dengan munculnya beban biaya atas pinjaman yang dilakukan perusahaan. Semakin besar beban biaya yang harus ditanggung maka semakin besar pula risiko yang dihadapi perusahaan.

Menurut Brigham \& Houston (2011), kebijakan dividen adalah keputusan mengenai berapa banyak laba saat ini yang akan dibayarkan sebagai dividen sebagai ganti dari dipertahankan untuk diinvestasikan kembali di dalam perusahaan. keputusan yang dibuat oleh manajemen untuk menentukan berapa besarnya laba yang akan dibagikan kepada investor atau perusahaan lebih memilih untuk tidak membagikan dividen, karena akan digunakan sebagai laba ditahan untuk membiayai pendanaan perusahaan.

Pertumbuhan penjualan yang tinggi akan mendorong peningkatan biaya operasional melalui utang. Menurut Brigham dan Houston (2011), bagi perusahaan dengan tingkat penjualan dan laba yang tinggi kecenderungan perusahaan tersebut menggunakan utang sebagai sumber dana eksternal yang lebih besar dibandingkan perusahaan-perusahaan yang tingkat penjualannya rendah. Pertumbuhan penjualan diukur dengan rasio sales growth. Rata-rata sales growth menunjukkan hasil yang fluktuatif. Setiap perusahaan berusaha mencapai pertumbuhan yang tinggi setiap tahunnya karena pertumbuhan perusahaan memberikan gambaran perkembangan perusahaan yang terjadi. Menurut Brigham dan Houston (2011) menyatakan bahwa perusahaan yang memiliki pertumbuhan lebih cepat harus lebih mengandalkan diri pada modal eksternal.

Tangibility dapat diartikan sebagai tingkat besarnya jaminan yang dapat diberikan perusahaan kepada pemberi utang. Tingginya rasio fixedto-total assets memberikan tingkat 
keamanan yang tinggi kepada pemberi utang; perusahaan dapat melikuidasi aset ketika perusahaan mengalami kebangkrutan. Sebaliknya, rasio fixedto-total assets yang rendah akan memberikan jaminan yang rendah pula bagi pemberi utang ketika kebangkrutan terjadi pada perusahaan (Baker \& Martin, 2011).

Penelitian dari Murningtyas (2012) menunjukan bahwa risiko bisnis berpengaruh negatif dan signifikan terhadap kebijakan hutang, hal tersebut bertentangan dengan penelitian Yeniatie dan Destriana (2010) yang menunjukkan bahwa risiko bisnis tidak berpengaruh signifikan terhadap kebijakan hutang.Hasil penelitian Murni dan Adriana (2007) yang menunjukkan hasil yang signifikan antara kebijakan deviden terhadap kebijakan hutang. Bertentangan dengan Jabid (2009) yang mendapatkan hasil bahwa kebijakan deviden memiliki pengaruh berbeda terhadap kebijakan hutang.

Hasil penelitian yang dilakukan oleh Hidayat (2013), menunjukkan bahwa pertumbuhan penjualan berpengaruh positif terhadap kebijakan utang.Sedangkan penelitian yang dilakukan Damayanti dan Hartini (2012), menunjukkan bahwa pertumbuhan penjualan secara parsial tidak berpengaruh terhadap kebijakan utang. Hasil penelitian Yeniatie dan Destriana (2010) menunjukkan bahwa pertumbuhan perusahaan berpengaruh terhadap kebijakan hutang. Sebaliknya, hasil penelitian Indahningrum dan Handayani (2009), Steven dan Lina (2011) serta Susanto (2011) menyatakan bahwa pertumbuhan perusahaan tidak berpengaruh terhadap kebijakan hutang.

Berdasarkan

Margaretha mempunyai
(2014), pengaruh penelitian tangibility positif dan signifikan terhadap kebijakan utang perusahaan.Perusahaan yang memiliki aset tetap besar cenderung menggunakan utang sebagai sumber pendanaan ketika pendanaan secara internal tidak cukup. Dalam penelitian Milanto (2012), tangibility tidak memiliki pengaruh pada kebijakan utang dengan arah negatif. Penelitian yang dilakukan Arfina (2015) tangibility tidak berpengaruh dan memiliki hubungan positif terhadap kebijakan hutang

Industri manufaktur merupakan industry yang mendominasi perusahaan-perusahaan yang terdaftar di Bursa Efek Indonesia (BEI). Sekitar 152 perusahaan dalam industri manufaktur tersebut dikelompokkan menjadi beberapa sub kategori industri. Pertumbuhan industri manufaktur dipicu oleh tingginya permintaan domestik dan cepatnya pertumbuhan investasi asing.Untuk memenuhi permintaan domestik yang tinggi, perusahaan harus melakukan ekspansi. Kegiatan ekspansi ini didanai oleh sumber dana internal dan eksternal. Salah satu sumber dana eksternal perusahaan adalah hutang.

Tujuan dari penelitian ini adalah melakukan pengujian kembali sekaligus mengembangkan penelitian sebelumnya terkait dengan kebijakan hutang perusahaan manufaktur di BEl karena adanya temuan ketidakkonsistenan diantara hasil penelitian-penelitian sebelumnya.

\section{B. KAJIAN TEORI}

\section{Kebijakan Hutang}

Menurut Riyanto (2011), Kebijakan hutang merupakan keputusan yang sangat penting dalam perusahaan. Dimana kebijakan hutang merupakan salah satu bagian dari kebijakan pendanaan perusahaan. Kebijakan hutang adalah kebijakan yang diambil pihak manajemen dalam 
rangka memperoleh sumber daya pembiayaan bagi perusahaan sehingga dapat digunakan untuk membiayai aktivitas operasional perusahaan.

Dalam penentuan kebijakan hutang, dipengaruhi oleh beberapa faktor.Baik faktor yang berasal dari dalam perusahaan maupun faktor yang berasal dari luar perusahaan. Menurut Mamduh (2004), terdapat beberapa faktor yang memiliki pengaruh terhadap kebijakan hutang, antara lain :

a. NDT (Non-Debt Tax Shield)

Manfaat dari penggunaan hutang adalah bunga hutang yang dapat digunakan untuk mengurangi pajak perusahaan. Namun untuk mengurangi pajak, perusahaan dapat menggunakan cara lain seperti depresiasi dan dana pensiun. Dengan demikian, perusahaan dengan NDT tinggi tidak perlu menggunakan hutang yang tinggi.

b. Struktur Aktiva

Besarnya aktiva tetap suatu perusahaan dapat menentukan besarnya penggunaan hutang.Perusahaan yang memiliki aktiva tetap dalam jumlah besar dapat menggunakan hutang dalam jumlah besar karena aktiva tersebut dapat digunakan sebagai jaminan pinjaman.

c. Profitabilitas

Perusahaan dengan tingkat pengembalian yang tinggi atas investasinya akan menggunakan hutang yang relatif kecil. Laba ditahannya yang tinggi sudah memadai membiayai sebagian besar kebutuhan pendanaan.

d. Risiko Bisnis

Perusahaan yang memiliki risiko bisnis yang tinggi akan menggunakan hutang yang lebih kecil untuk menghindari risiko kebangkrutan.

e. Struktur kepemilikan institusional

Perusahaan yang besar cenderung terdiversifikasi sehingga menurunkan risiko kebangkrutan. Di samping itu, perusahaan yang besar lebih mudah dalam mendapatkan pendanaan eksternal.

f. Kondisi Internal Perusahaan

Kondisi internal perusahaan menentukan kebijakan penggunaan hutang dalam suatu perusahaan.

\section{Risiko Bisnis}

Perusahaan memiliki sejumlah risiko yang didapat langsung akibat dari jenis usaha dari perusahaan tersebut, hal inilah yang dimaksud dengan risiko bisnis.Risiko bisnis menurut Brigham dan Houston (2011) adalah seberapa berisiko saham perusahaan jika perusahaan tidak mempergunakan hutang.Risiko bisnis tidak hanya bervariasi dari industri ke industri, namun juga dapat bervariasi antar perusahaan dari industri tertentu, dan juga dapat berganti seiring waktu. Brigham dan Houston (2011) menunjukkan beberapa faktor yang dapat memengaruhi risiko bisnis dari sebuah perusahaan, antara lain:

a. Variabilitas permintaan; semakin stabil sebuah permintaanproduk dari perusahaan tertentu, ceteris paribus, akanmenurunkan risiko bisnis perusahaan tersebut.

b. Variabilitas harga jual; perusahaan yang produknya dijual pada pasar yang relatif volatile (mudah berubah), akan lebih memilikirisiko bisnis bila dibandingkan dengan perusahaan yang sama yang harga outputnya lebih stabil. 
c. Variabilitas biaya input; perusahaan yang memiliki biaya input yang tidak pasti akan memiliki risiko bisnis yang tinggi.

d. Kemampuan untuk menyesuaikan harga output denganperubahan dalam biaya input; semakin mampu sebuahperusahan dalam melakukan penyesuaian dalam hal harga danbiaya, maka perusahaan tersebut memiliki risiko bisnis yang semakin rendah.

e. Kemampuan untuk mengembangkan produk baru dalam waktu dan biaya yang efektif. Perusahaan seperti obatobatan dan juga komputer sangat bergantung pada inovasi produkproduk baru. Semakin cepat sebuah produk menjadi tua atau usang, maka semakin besar pula risiko bisnisnya.

f. Risiko dari perdagangan luar negeri; perusahan yang pendapatannya sebagian besar datang dari luar negeri dapat membuat pendapatan perusahaan menurun, hal ini dikarenakan adanya fluktuasi nilai kurs mata uang. Hal lain yang dapatmenambahkan risiko bisnis adalah lingkungan bisnis di manaperusahaan tersebut beroperasi.

g. Proporsi biaya tetap terhadap keseluruhan biaya: operating leverage; jika sebagian besar biaya adalah tetap, yang tidakturun ketika permintaan menurun, maka perusahaan tersebut memiliki risiko bisnis yang tinggi.

\section{Kebijakan Dividen}

Kebijakan dividen adalah keputusan mengenai apakah laba yang diperoleh perusahaan akan dibagikan kepada para pemegang saham sebagai dividen atau akan ditahan dalam bentuk laba ditahan guna pembiayaan investasi dimasa yang akan datang. Dalam kebijakan dividen terdapat trade off dan merupakan pilihan yang tidak mudah antara membagikan laba sebagai dividen atau diinvestasikan kembali. Apabila perusahaan memilih membagikan laba sebagai dividen maka tingkat pertumbuhan akan berkurang dan berdampak negatif terhadap saham. Disisi lain, apabila perusahaan tidak membagikan dividen maka pasar akan memberikan sinyal negatif kepada prospek perusahaan. peningkatan dividen memberikan sinyal perubahan yang menguntungkan pada harapan manajer dan penurunan dividen menunjukkan pandangan pesimis prospek perusahaan dimasa yang akan datang (Sartono dan Prasetyanta, 2005).

\section{Pertumbuhan Penjualan}

Menurut Brigham dan Houston (2011) perusahaan dengan penjualan yang relatif stabil dapat lebih aman memperoleh lebih banyak pinjaman dan menanggung beban tetap yang lebih tinggi dibandingkan dengan perusahaan yang penjualannya tidak stabil. Pertumbuhan penjualan merupakan signal pada kreditur untuk memberikan kredit atau bagi bank sebagai kreditor untuk menambah kredit, sehingga pertumbuhan penjualan mempunyai pengaruh positif terhadap struktur modal. Perusahaan yang mempunyai tingkat penjualan yang tinggi akan lebih menguntungkan jika memakai hutang (Mamduh, 2004). Menurut teori signaling maka pertumbuhan penjualan mempunyai pengaruh positif terhadap struktur modal. 


\section{Pertumbuhan Perusahaan}

Pertumbuhan perusahaan adalah tingkat perubahan total aset dari tahun ke tahun (Yeniatie dan Destriana, 2010). Menurut Steven dan Lina (2011), pertumbuhan perusahaan adalah gambaran mengenai perkembangan perusahaan. Perusahaan yang memiliki pertumbuhan lebih cepat harus lebih mengandalkan dana dari modal eksternal. Selain itu, baiya emisi yang berkaitan dengan penjualan saham biasa akan melebihi biaya emisi yang terjadi ketika perusahaan menjual hutang, mendorong perusahaan yang mengalami pertumbuhan pesat untuk lebih mengandalkan diri pada hutang. Namun, pada waktu yang bersamaan, perusahaan tersebut sering kali menghadapi ketidak pastian yang lebih tinggi, cenderung akan menurunkan keinginan mereka untuk menggunakan hutang (Brigham dan Houston, 2011).

\section{Tangibility}

Tangibility dapat diartikan sebagai tingkat besarnya jaminan yang dapat diberikan perusahaan kepada pemberi utang. Tingginya rasio fixed-tototal assets memberikan tingkat keamanan yang tinggi kepada pemberi utang; perusahaan dapat melikuidasi aset ketika perusahaan mengalami kebangkrutan. Sebaliknya, rasio fixedto-total assets yang rendah akan memberikan jaminan yang rendah pula bagi pemberi utang ketika kebangkrutan terjadi pada perusahaan (Baker \& Martin, 2011).

\section{Kerangka Pemikiran}

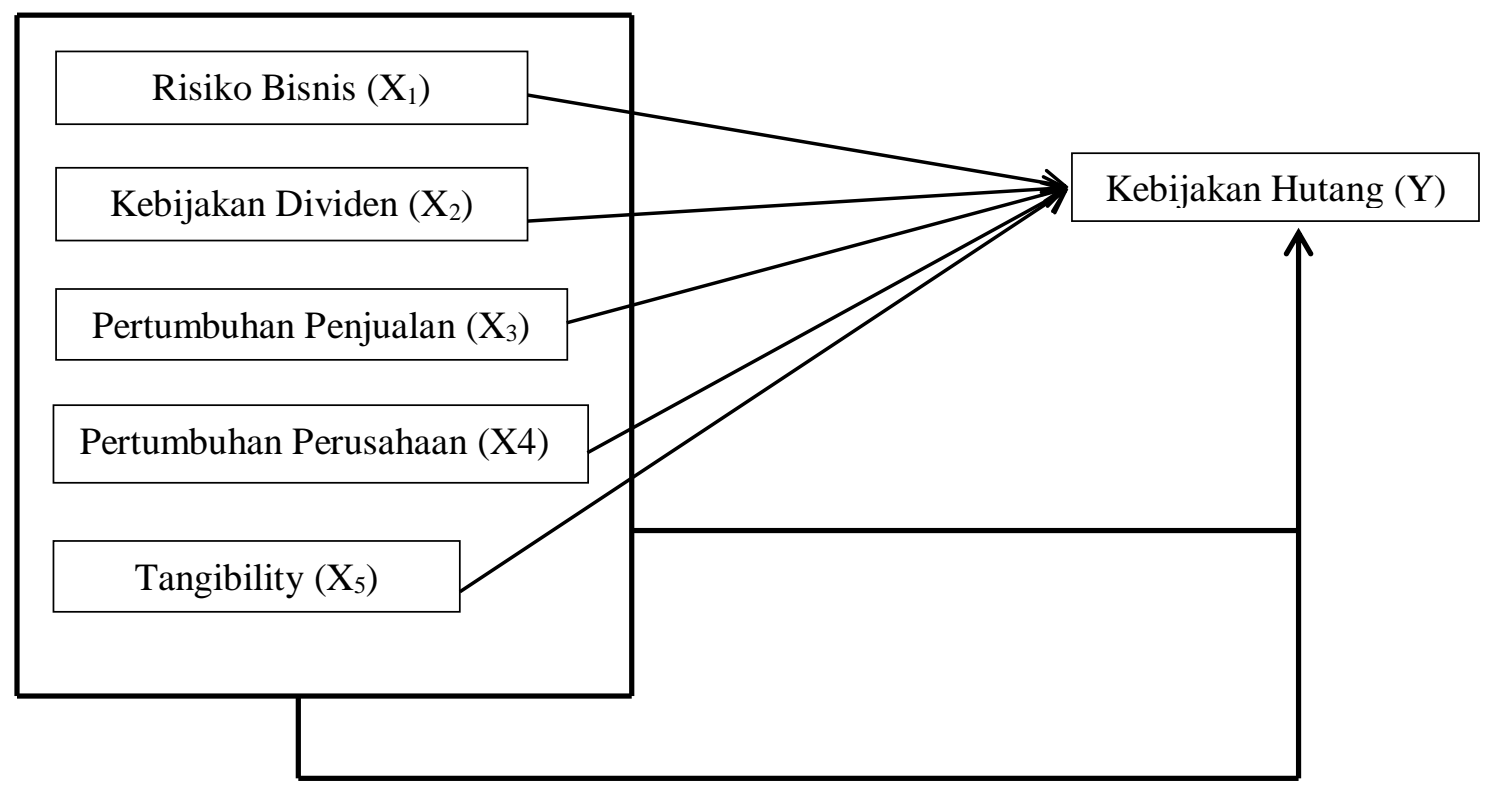

Gambar 1. Kerangka Pemikiran

\section{METODE PENELITIAN}

Ruang lingkup dalam penelitian ini penulis menggunakan perusahaan manufaktur yang terdaftar di Bursa Efek Indonesia periode tahun 2014 2018 dengan variable terikat kebijakan hutang (DER) dan lima variabel independen yang diteliti diantaranya resiko bisnis yang diukur dengan $\mathrm{DOL}$ (Degree Of Operating Laverage), kebijakan deviden yang diukur dengan DPR (Dividend Payout Ratio), pertumbuhan penjualan yang diukur dengan GS (Growth Sales), pertumbuhan perusahaan yang diukur dengan Growth (Growth Opportunity), 
dan tangibility yang diukur dengan AST (Assets Tangibility).

Populasi pada penelitian ini adalah seluruh perusahaan manufaktur yang terdaftar di BursaEfek Indonesia (BEl) dari tahun 2014-2018 yaitu sejumlah 152 perusahaan. Teknik pengumpulan data yang digunakan dalam penelitian ini yaitu teknik purposive sampling.Berdasarkan kriteria yang ditentukan maka diperoleh sampel sebanyak 28 (dua puluh delapan) perusahaan.Penelitian ini juga menggunakan analisis regresi linier berganda untuk analisis pengaruh dari variabel bebas terhadap variabel
terikat.Persamaan regresi linear sederhana pada penelitian ini adalah sebagai berikut:

$Y=\alpha+\beta_{1} X_{1}+\beta_{2} X_{2}+\beta_{3} X_{3}+\beta_{4} X_{4}+\beta_{5} X_{5}+e$

\section{HASIL PENELITIAN}

\section{Uji Asumsi Klasik}

\section{Keterangan :}

$\mathrm{Y}=$ Kebijakan Hutang

$\alpha=$ Nilai Konstanta

$\beta 1,2,3,4,5=$ Koefisien Regresi

$\mathrm{X} 1=$ Risiko Bisnis pada perusahaan

$\mathrm{X} 2=$ Kebijakan Deviden pada perusahaan

X3=Pertumbuhan Penjualan pada perusahaan

X4=Pertumbuhan Perusahaan pada

perusahaan

X5 = Tangibility

e = Standard Error

\section{Tabel Uji Normalitas}

One-Sample Kolmogorov-Smirnov Test

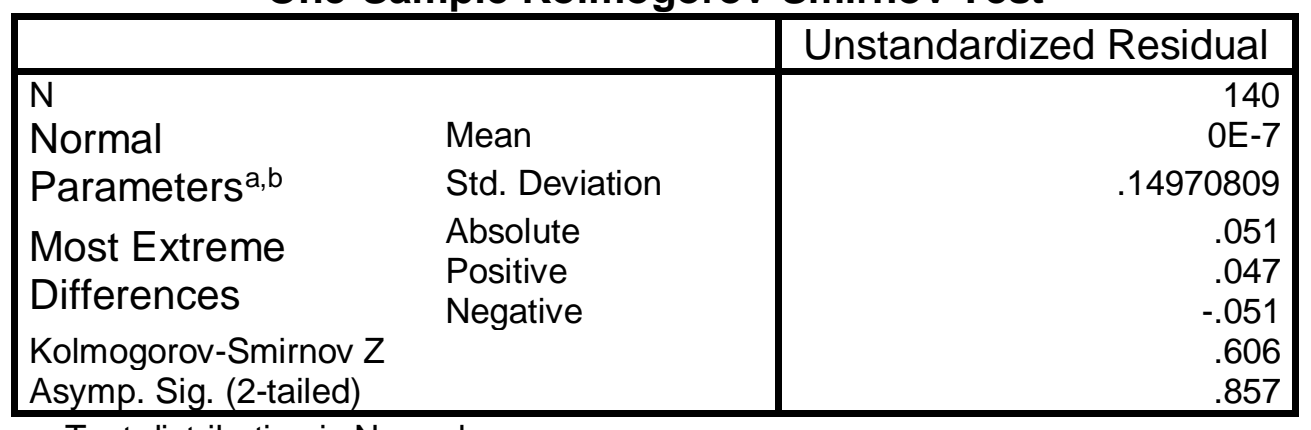

a. Test distribution is Normal.

b. Calculated from data.

Sumber : Hasil olah data 2020

Tabel Uji Multikolinieritas

Coefficients $^{\mathrm{a}}$

\begin{tabular}{|c|c|c|c|c|c|c|c|c|}
\hline \multirow{2}{*}{ Model } & \multicolumn{2}{|c|}{$\begin{array}{l}\text { Unstandardize } \\
\text { d Coefficients }\end{array}$} & \multirow{2}{*}{$\begin{array}{c}\begin{array}{c}\text { Standardized } \\
\text { Coefficients }\end{array} \\
\text { Beta }\end{array}$} & \multirow{2}{*}{$t$} & \multirow{2}{*}{ Sig. } & \multicolumn{2}{|c|}{$\begin{array}{c}\text { Collinearity } \\
\text { Statistics }\end{array}$} & \multirow{2}{*}{ KET } \\
\hline & B & $\begin{array}{l}\text { Std. } \\
\text { Error }\end{array}$ & & & & $\begin{array}{c}\text { Toleranc } \\
\mathrm{e}\end{array}$ & VIF & \\
\hline (Constant) & .268 & .034 & & 8.011 & .000 & & & \\
\hline Risiko Bisnis & -.095 & .093 & -.083 & -1.020 & .310 & .949 & $\begin{array}{r}1.05 \\
4\end{array}$ & $\begin{array}{l}\text { Tidak Terjadi } \\
\text { multikolinieritas }\end{array}$ \\
\hline $\begin{array}{l}1 \text { Kebijakan } \\
\text { Deviden }\end{array}$ & .001 & .003 & .031 & .387 & 699 & .995 & $\begin{array}{r}1.00 \\
5\end{array}$ & $\begin{array}{l}\text { Tidak Terjadi } \\
\text { multikolinieritas }\end{array}$ \\
\hline $\begin{array}{l}\text { Pertumbuhan } \\
\text { Penjualan }\end{array}$ & .130 & .072 & .147 & 1.802 & .074 & .934 & $\begin{array}{r}1.07 \\
1\end{array}$ & $\begin{array}{l}\text { Tidak Terjadi } \\
\text { multikolinieritas }\end{array}$ \\
\hline
\end{tabular}




\begin{tabular}{|l|r|r|r|r|r|r|r|l|}
$\begin{array}{l}\text { Pertumbuhan } \\
\text { Perusahaan }\end{array}$ & -.071 & .041 & -.142 & -1.745 & .083 & .942 & $\begin{array}{r}1.06 \\
1\end{array}$ & $\begin{array}{l}\text { Tidak Terjadi } \\
\text { multikolinieritas } \\
\text { Tangibility }\end{array}$ \\
\hline
\end{tabular}

a. Dependent Variable: Kebijakan Hutang

Sumber: Hasil olah data 2020

\section{Tabel Uji HeteroskedastisitasSetelah Transformasi Data Coefficients $^{a}$}

\begin{tabular}{|c|c|c|c|c|c|c|c|}
\hline \multirow{2}{*}{\multicolumn{2}{|c|}{ Model }} & \multicolumn{2}{|c|}{$\begin{array}{c}\text { Unstandardized } \\
\text { Coefficients }\end{array}$} & \multirow{2}{*}{$\begin{array}{c}\text { Standardized } \\
\text { Coefficients } \\
\text { Beta }\end{array}$} & \multirow[t]{2}{*}{$\mathrm{t}$} & \multirow[t]{2}{*}{ Sig. } & \multirow[t]{2}{*}{ KET } \\
\hline & & $B$ & $\begin{array}{l}\text { Std. } \\
\text { Error }\end{array}$ & & & & \\
\hline \multirow{6}{*}{1} & (Constant) & .285 & .127 & & 2.248 & .027 & \\
\hline & Ln_X1 & -.014 & .021 & -.068 & -.638 & .525 & $\begin{array}{l}\text { Tidak Terjadi } \\
\text { Heteroskedastisitas }\end{array}$ \\
\hline & Ln_X2 & -.015 & .023 & -.070 & -.674 & .502 & $\begin{array}{l}\text { Tidak Terjadi } \\
\text { Heteroskedastisitas }\end{array}$ \\
\hline & Ln_X3 & -.056 & .029 & -.202 & -1.957 & .053. & $\begin{array}{l}\text { Tidak Terjadi } \\
\text { Heteroskedastisitas }\end{array}$ \\
\hline & Ln_X4 & .016 & .022 & .076. & .743 & .459. & $\begin{array}{l}\text { Tidak Terjadi } \\
\text { Heteroskedastisitas }\end{array}$ \\
\hline & Ln_X5 & .091. & .070 & 137 & 1.301 & 197 & $\begin{array}{l}\text { Tidak Terjadi } \\
\text { Heteroskedastisitas }\end{array}$ \\
\hline
\end{tabular}

a. Dependent Variable: Abs_Res

Sumber : Hasil olah data 2020

Tabel Hasil Uji Autokorelasi setelah Transformasi Model Summary ${ }^{b}$

\begin{tabular}{|l|r|r|r|r|r|r|}
\hline Model & \multicolumn{1}{|c|}{$R$} & $R$ Square & $\begin{array}{c}\text { Adjusted } R \\
\text { Square }\end{array}$ & $\begin{array}{r}\text { Std. Error of } \\
\text { the Estimate }\end{array}$ & \multicolumn{1}{|c|}{$\begin{array}{l}\text { Durbin- } \\
\text { Watson }\end{array}$} & KET \\
\hline 1 & $.323^{\mathrm{a}}$ & .104 & .070 & .09905 & 1.954 & $\begin{array}{l}\text { Tidak Terjadi } \\
\text { Autokorelasi }\end{array}$ \\
\hline
\end{tabular}

a. Predictors: (Constant), Lag_X5, Lag_X1, Lag_X2, Lag_X3, Lag_X4

b. Dependent Variable: Lag $Y$

Sumber : Hasil olah data 2020

\section{Analisis Regresi Linier Berganda}

\section{Tabel Hasil Analisis Regresi Linier Berganda Coefficients $^{\mathrm{a}}$}

\begin{tabular}{|l|r|r|r|r|r|}
\hline Model & \multicolumn{2}{|c|}{$\begin{array}{c}\text { Unstandardized } \\
\text { Coefficients }\end{array}$} & \multicolumn{1}{c|}{$\begin{array}{c}\text { Standardized } \\
\text { Coefficients }\end{array}$} & \multicolumn{1}{c|}{ Sig. } \\
\cline { 2 - 3 } & \multicolumn{1}{|c|}{$\mathrm{B}$} & Std. Error & \multicolumn{1}{c|}{ Beta } & & \\
\hline \multirow{3}{*}{ (Constant) } & .268 & .034 & & 8.011 & .000 \\
Risiko Bisnis & -.095 & .093 & -.083 & -1.020 & .310 \\
Kebijakan Deviden & .001 & .003 & .031 & .387 & .699 \\
Pertumbuhan & .130 & .072 & .147 & 1.802 & .074 \\
\hline
\end{tabular}




\begin{tabular}{|l|r|r|r|r|r|}
\hline Pertumbuhan & -.071 & .041 & -.142 & -1.745 & .083 \\
Perusahaan & .358 & .087 & .337 & 4.097 & .000 \\
\hline
\end{tabular}

a. Dependent Variable: Kebijakan Hutang

Sumber: Hasil olah data, 2020

Dari perhitungan regresi linier berganda diatas, maka diperoleh bentuk persamaan regresi linier berganda dari penelitian ini adalah sebagai berikut:

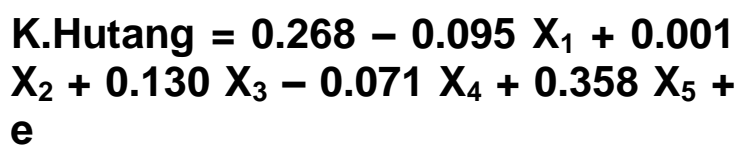

\section{Tabel Uji Hipotesis Secara Parsial (F)} ANOVA $^{\mathrm{a}}$

\begin{tabular}{|rl|r|r|r|r|l|}
\hline Model & \multicolumn{1}{|c|}{$\begin{array}{c}\text { Sum of } \\
\text { Squares }\end{array}$} & Df & Mean Square & F & Sig. \\
\hline \multirow{4}{*}{1} & Regression & .617 & 5 & .123 & 5.188 & $.000^{\mathrm{b}}$ \\
& Residual & 3.185 & 134 & .024 & & \\
& Total & 3.802 & 139 & & & \\
\hline
\end{tabular}

a. Dependent Variable: Kebijakan Hutang

b. Predictors: (Constant), Tangibility, Kebijakan Deviden, Resiko Bisnis, Pertumbuhan Perusahaan, Pertumbuhan Penjualan

Sumber: Hasil olah data, 2020

Berdasarkan hasil pengujian hipotesis secara simultan (F), maka dapat diketahui bahwa secara simultan variabel independen memiliki pengaruh yang signifikan terhadap variabel dependen. Hasil ini dibuktikan dari nilai $F$ hitung sebesar 5,188 dengan probabilitinya 0,000 . Karena probabilitasnya lebih kecil dari 0,05 dan $F$ hitung $>F$ tabel $(5.188>2.44)$, dengan $\mathrm{F}$ tabel yang didapat dari rumus $\mathrm{N}_{1}=\mathrm{K}-1$ dan $\mathrm{N}_{2}=\mathrm{n}-\mathrm{k}$.

Maka model regresi ini dapat digunakan untuk memprediksi pendapatan premi. Resiko Bisnis, Kebijakan Deviden, Pertumbuhan Penjualan, Pertumbuhan Perusahaan dan Tangibility secara simultan berpengaruh terhadap Kebijakan Hutang.

Tabel Hasil Uji Statistik t

Coefficients $^{\mathrm{a}}$

\begin{tabular}{|l|r|r|r|r|r|}
\hline \multirow{2}{*}{ Model } & \multicolumn{2}{|c|}{$\begin{array}{c}\text { Unstandardized } \\
\text { Coefficients }\end{array}$} & $\begin{array}{c}\text { Standardized } \\
\text { Coefficients }\end{array}$ & \multicolumn{1}{c|}{ Sig. } & \\
\cline { 2 - 4 } & \multicolumn{1}{|c|}{ B } & Std. Error & \multicolumn{1}{c|}{ Beta } & & \\
\hline (Constant) & .268 & .034 & & 8.011 & .000 \\
Risiko Bisnis & -.095 & .093 & -.083 & -1.020 & .310 \\
Kebijakan Deviden & .001 & .003 & .031 & .387 & .699 \\
Pertumbuhan & .130 & .072 & .147 & 1.802 & .074 \\
Penjualan & & & & & \\
Pertumbuhan & -.071 & .041 & -.142 & -1.745 & .083 \\
Perusahaan & .358 & .087 & .337 & 4.097 & .000 \\
Tangibility & & & & \\
\hline
\end{tabular}

a. Dependent Variable: Kebijakan Hutang

Sumber: Hasil olah data, 2020 

Berdasarkan hasil pengujian melalui program aplikasi SPSS Versi 20 pada tabel diatas, maka dapat diambil penjelasan sebagai berikut:

1. Pengujian hipotesis pada variabel independen risiko bisnis

Pada hipotesis parsial $\mathrm{H}_{1}$ menyatakan bahwa resiko bisnis tidak berpengaruh terhadap kebijakan hutang. Hasil uji statistik diatas menunjukan bahwa thitung $<$ t-tabel $=(-1.020<1.977)$ dan $0.310>0.05$ (tidak signifikan), dengan hasil diatas maka resiko bisnis tidak berpengaruh signifikan terhadap kebijakan hutang.

2. Pengujian hipotesis pada variabel independen kebijakan deviden

Pada hipotesis parsial $\mathrm{H}_{2}$ menyatakan bahwa kebijakan deviden tidak berpengaruh terhadap kebijakan hutang. Hasil uji statistik diatas menunjukan bahwa t-hitung <t-tabel = $(0,387<1.977)$ dan $0.699>0.05$ (tidak signifikan), dengan hasil diatas maka kebijakan deviden tidak berpengaruh signifikan terhadap kebijakan hutang.

3. Pengujian hipotesis pada variabel independen

pertumbuhan

penjualan

Pada hipotesis parsial $\mathrm{H}_{3}$ menyatakan bahwa pertumbuhan penjualan tidak berpengaruh terhadap kebijakan hutang. Hasil uji statistik diatas menunjukan bahwa t-hitung<t-tabel = $(1.802<1.977)$ dan $0,074>0.05$ (tidak signifikan), dengan hasil diatas maka pertumbuhan penjualan tidak berpengaruh signifikan terhadap kebijakan hutang.

4. Pengujian hipotesis pada variabel independen

pertumbuhan

perusahaan

Pada hipotesis parsial $\mathrm{H}_{4}$ menyatakan bahwa pertumbuhan perusahaan tidak berpengaruh terhadap kebijakan hutang. Hasil uji statistik diatas menunjukan bahwa t-hitung <t-tabel $=(-$ $1.745<1.977)$ dan $0,083>0.05$ (tidak signifikan), dengan hasil diatas maka pertumbuhan perusahaan tidak berpengaruh signifikan terhadap kebijakan hutang.

5. Pengujian hipotesis pada variabel independen tangibility

Pada hipotesis parsial $\mathrm{H}_{5}$ menyatakan bahwa tangibility berpengaruh terhadap kebijakan hutang. Hasil uji statistik diatas menunjukan bahwa t-hitung <t-tabel $=(4.097>1.977)$ dan $0,000<0.05$ (signifikan), dengan hasil diatas maka tangibility berpengaruh positif signifikan terhadap kebijakan hutang.

Tabel Koefisien Determinasi Model Summary

\begin{tabular}{|l|r|r|r|r|}
\hline Model & $\mathrm{R}$ & $\begin{array}{c}\mathrm{R} \\
\text { Square }\end{array}$ & $\begin{array}{c}\text { Adjusted R } \\
\text { Square }\end{array}$ & $\begin{array}{c}\text { Std. Error of } \\
\text { the Estimate }\end{array}$ \\
\hline 1 & $.403^{\mathrm{a}}$ & .162 & .131 & .15418030 \\
\hline
\end{tabular}

a. Predictors: (Constant), Tangibility, Kebijakan Deviden, Resiko Bisnis,

Pertumbuhan Perusahaan, Pertumbuhan Penjualan

Sumber: Hasil olah data, 2020

Dari tabel diatas memperlihatkan bahwa nilai untuk $R$ Square adalah sebesar 0.162. Hal tersebut memiliki arti bahwa variabel independen yakni risiko bisnis, kebijakan deviden, pertumbuhan penjualan, pertumbuhan 
perusahaan dan tangibility mempengaruhi variabel dependen yaitu kebijakan hutang sebesar $16,2 \%$, sedangkan $83,8 \%$ dijelaskan oleh variabel lain yang tidak diteliti dalam model penelitian ini.

\section{E. PEMBAHASAN}

Berdasarkan pengujian secara simultan yang telah dilakukan menunjukan bahwa secara simultan terdapat pengaruh yang signifikan variabel Risiko Bisnis, Kebijakan Deviden, Pertumbuhan Penjualan, Pertumbuhan Perusahaan dan Tangibilityterhadap Kebijakan Hutang. Nilai sig F diperoleh sebesar 0,000. Hal ini menunjukan probabilitas lebih kecil dari 0,05 sehingga dapat disimpulkan Risiko Bisnis, Kebijakan Deviden, Pertumbuhan Penjualan, Pertumbuhan Perusahaan dan Tangibilitymempunyai pengaruh positif secara simultan terhadap Kebijakan Hutang pada perusahaan manufaktur yang terdaftar di BEI pada tahun 20142018.

Maka dapat dikatakan bahwa variabel-variabel yang diteliti memiliki kontribusi yang cukup dalam kebijakan hutang. Dengan variabel tersebut akan membantu pihak manajerial dan pemilik perusahaan dalam memutuskan suatu kebijakan hutang.Hasil penelitian ini sesuai dengan penelitian yang dilakukan oleh Steven dan Lina (2011), Mardiyati, dkk (2016) dan Arfina (2015) yang menyatakan bahwa kebijakan deviden secara simultan memiliki pengaruh yang signifikan terhadap kebijakan hutang.

Risiko bisnis tidak berpengaruh secara signifikan terhadap kebijakan hutang.Hal ini berarti risiko bisnis kurang diperhatikan oleh pihak perusahaan dalam menentukan besar kecilnya hutang. Hal ini terjadi perbedaan pendapat antara pihak perusahaan dan investor karena investor cenderung menyukai risiko bisnis yang tinggi karena diharapkan dengan risiko bisnis yang tinggi maka semakin tinggi juga pengembalian atau return yang diperoleh.

Hal ini berarti pada saat perusahaan menggunakan proporsi utang yang tinggi, artinya operating leveragefinansial perusahaan yang tinggi, minat investor akan menurun, sehingga harga saham perusahaan menurun, disebabkan kondisi pasar perusahaan tersebut yaitu permintaan terhadap sahamnya yang menurun. Hal ini akan berpengaruh terhadap hutang perusahaan yang mencerminkan risiko yang dialami perusahaan akan meningkat.

Hasil penelitian ini sejalan dengan penelitian yang dilakukan oleh Yeniatie dan Destriana (2010) dengan topik Faktor-Faktor yang Mempengaruhi Kebijakan Hutang Pada Perusahaan Non Keuangan yang Terdaftar Di Bursa Efek Indonesia, menyatakan bahwa risiko bisnis tidak berpengaruh signifikan terhadap kebijakan hutang.Penelitian ini mendukung trade-off theory, bahwa adanya manfaat pajak akibat penggunaan hutang, sehingga perusahaan akan menggunakan hutang sampai tingkat tertentu untuk memaksimalkan nilai perusahaan.

Kebijakan deviden tidak berpengaruh secara signifikan terhadap kebijakan hutang.Dividen merupakan pembayaran dari perusahaan kepada para pemegang saham atas keuntungan yang diperolehnya.Kebijakan dividen adalah kebijakan yang berhubungan dengan pembayaran dividen oleh pihak perusahaan, berupa penentuan besarnya dividen yang dibagikan dan besarnya saldo laba yang ditahan untuk kepentingan perusahaan (Sutrisno, 2001).peningkatan dividen 
memberikan sinyal perubahan yang menguntungkan pada harapan manajer dan penurunan dividen menunjukkan pandangan pesimis prospek perusahaan dimasa yang akan datang (Sartono dan Prasetyanta, 2005).

Deviden merupakan bagian dari keuntungan yang dibagikan kepada para pemegang saham.Kebijakan deviden diambil terkait dengan jumlah arus kas dalam perusahaan. Ketika dana yang didapat akan dibagikan sebagai deviden, maka perusahaan akan cenderung untuk menggunakan hutang. Sebaliknya, jika dana yang didapat tidak dibagikan sebagai deviden maka perusahaan kemungkinan tidak akan menggunakan hutang.

Hasil penelitian ini mendukung penelitian yang dilakukan oleh Murtiningtyas (2012) dengan topik PengaruhKebijakan Dividen, Kepemilikan Manajerial, Kepemilikan Institusional,Profitabilitas dan Risiko Bisnis Terhadap Kebijakan Hutang menyatakan bahwa kebijakan deviden tidak berpengaruh terhadap kebijakan hutang.

Pertumbuhan Penjualan tidak berpengaruh secara signifikan terhadap kebijakan hutang.Perusahaan yang memiliki penerimaan tinggi, berarti memiliki kemampuan pendanaan internal yang tinggi. Sesuai dengan teori pecking order, perusahaan akan memilih pendanaan internal terlebih dahulu kemudian hutang dan saham sebagai pilihan terakhir.

Tingkat pertumbuhan terhadap hutang didasarkan pada kenyataan semakin tinggi pertumbuhan perusahaan maka semakin tinggi pula struktur modal perusahaan berupa hutang jangka panjang.Selain itu, Semakin tinggi pertumbuhan pasar maka peluang bisnis perusahaan semakin besar.Semakin stabil juga pertumbuhan penjualannya. Ketika dana internal berupa pendapatan penjualan perusahaan tidak mencukupi, maka perusahaan dapat dengan aman menggunakan hutang karena penjualan yang stabil maka perusahaan akan mampu membayar biaya tetap yang ditimbulkan dari hutang.

Hasil penelitian ini tidak mendukung penelitian terdahulu yang telah dilakukan oleh Mardiyati, dkk (2016) dengan topik Pengaruh Kepemilikan Manajerial, Struktur Aktiva, Ukuran Perusahaan, Pertumbuhan Penjualan dan Profitabilitas Terhadap Kebijakan Hutang menyatakan bahwa pertumbuhan penjualan dan profitabilitas berpengaruh positif signifikan terhadap kebijakan hutang.

Pertumbuhan Perusahaan tidak berpengaruh secara signifikan terhadap kebijakan hutang.Hasil penelitian ini tidak sependapat dengan penelitian yang menyatakan bahwa peningkatan asset didukung dengan meningkatnya hutang. Tingkat pertumbuhan yang tinggi akan meningkatkan jumlah aktiva yang dibutuhkan sehingga memerlukan dana yang lebih banyak untuk memenuhi aktiva tersebut.Hasil ini sejalan dengan teori Pecking Order, bahwa perusahaan lebih cenderung memilih menggunakan dana internal seperti modal sendiri dan laba ditahan dibandingkan dengan penggunaan dana ekternal seperti hutang, karena penggunaan hutang lebih berisiko

Perusahaan akan tetap memilih sumber pendanaan yang mempunyaiborrowing cost yang lebih murah dan lebih mengandalkan dana internal.Apabila pertumbuhan yang dialami perusahaan tersebut menyebabkan perusahaan tersebut membutuhkan dana lebih, maka 
kemungkinan mereka akan menerbitkan saham untuk mengumpulkan dana yang mempunyai borrowing cost lebih rendah daripada hutang.

Hasil penelitian ini tidak mendukung penelitian yang dilakukan Indahningrum dan Handayani (2009) Pengaruh Kepemilikan Manajerial, Kepemilikan Institusional, Dividen, Pertumbuhan Perusahaan, Free Cash Flow dan Profitabilitas terhadap Kebijakan Hutang Perusahaan menyatakan bahwa Pertumbuhan Perusahaan tidak berpengaruh terhadap kebijakan hutang.

Tangibility berpengaruh positif signifikan terhadap kebijakan hutang.Berdasarkan hasil penelitian menyatakan bahwa variabel tangibility tidak berpengaruh namun mempunyai hubungan positif terhadap kebijakan hutang.Hal ini sesuai dengan model pajak dan keagenan yang memperkirakan ada hubungan positif antara rasio aktiva tetap terhadap hutang karena aktiva tetap bisa dijadikan sebagai jaminan pinjaman (Mamduh, 2004). Hubungan positif tangibility terhadap kebijakan hutang menunjukkan bahwa semakin besar aset tetapnya, maka semakin besar pula jumlah hutangnya, hal ini dikarenakan perusahaan dengan jumlah aset tetap yang besar mempermudah perusahaan dalam memperoleh hutang karena salah satu persyaratan mengajukan pinjaman hutang adalah adanya aktiva tetap berwujud yang dapat dijadikan sebagai jaminan.

Tangibility dapat juga diartikan sebagai tingkat besarnya jaminan yang dapat ditawarkan perusahaan kepada pemberi utang dengan menghitung perbandingan antara fixed assets dan total assets. Dari hasil penelitian ini, berpengaruhnya tangibility terhadap kebijakan utang karena besar kecilnya fixed assets yang dimiliki perusahaan menjadi salah satu penentu utama bagi perusahaan dalam menentukan kebijakan utangnya.

Hasil penelitian ini mendukung penelitian yang dilakukan oleh Arfina (2015) dengan topik Pengaruh Tangibility, Profitabilitas, Growth, Risiko Bisnis, dan Likuiditas terhadap Kebijakan Hutang Pada Perushaan Manufaktur Sektor Industri Kimia Dan dasar yang terdaftar Di BEI menyatakan bahwa tangibility berpengaruh positif terhadap kebijakan hutang.

\section{F. KESIMPULAN}

1) Resiko bisnis, kebijaka deviden, pertumbuhan penjualan dan pertumbuhan perusahaan tidak berpengaruh terhadap kebijakan hutang pada perusahaan manufaktur yang terdaftar di Bursa Efek Indonesia.

2) Tangibility berpengaruh positif terhadap kebijakan hutang pada perusahaan manufaktur

\section{G. SARAN}

1) Bagi perusahaan, sebaiknya dalam menentukan kebijakaan hutang perusahaan harus mempertimbangkan beberapa faktor yang penting bagi perusahaan yaitu risiko perusahaan dan tangibility perusahaan. Perusahaan hendaknya menurunkan kebijakan hutangnya jika sedang memiliki risiko bisnis yang tinggi, karena akan semakin meningkatkan risiko bisnis perusahaan. Sebaliknya perusahaan dapat meningkatkan kebijakan hutangnya disaat tangibilitynya cukup besar, sehingga perusahaan memiliki nilai agunan yang besar untuk 
mendapatkan hutang jangka panjangnya.

2) Bagi peneliti selanjutnya yang ingin melanjutkan penelitian ini, untuk dapat menambah variabelvariabel yang belum diteliti dalam penelitian ini, hal ini dikarenakan terdapat beberapa variabel lain yang dapat mempengaruhi kebijakan hutang, seperti likuiditas, ukuran perusahaan, pajak dan lain-lain. Selain itu, penelitian dapat dilakukan dengan menggunakan periode berbeda. Sehingga akan menghasilkan gambaran yang lebih maksimal, lebih luas, dan lengkap.

\section{DAFTAR PUSTAKA}

Arfina, Winda. 2015, Pengaruh Tangibility, Profitabilitas, Growth, Risiko Bisnis Dan Likuiditas Terhadap Kebijakan Hutang Pada Perusahaan Manufaktur Sektor Industri Kimia Dan Dasar Yang Terdaftar Di Bei Periode 2011-2015. JOM Fekon, Vol. 4 No.2 (Oktober) 2017

Brigham, E.F., dan Houston, J.F. 2011. Dasar-dasar Manajemen Keuangan.Diterjemahkan oleh: Ali Akbar Yulianto. Edisi Kesebelas. Buku kedua. Jakarta: Salemba Empat.

Baker, H. K., dan Martin G. S. 2011. Capital Structure and Corporate Financing Decision:Theory, Evidence, and Practice. New Jersey: John Wiley and Sons.

Damayanti, Dinar, Hartini, Titin.2013.

Pengaruh

Likuiditas,

Profitabilitas,

Pertumbuhan

Penjualan Dan Ukuran

Perusahaan Terhadap Kebijakan
Hutang Pada Perusahaan Sektor Consumer Goods Di BEI Periode 2008-2012.STIE MDP.

Hidayat M.Syafiudin 2013. Pengaruh Kepemilikan Manajerial, Kebijakan Dividen, Struktur Aktiva, Pertumbuhan Penjualan, Dan Ukuran Perusahaan Terhadap Kebijakan Hutang, Jurnal IImu Manajemen. Vol 1 Nomor 1 Januari 2013, Jurusan Manajemen, Fakultas Ekonomi, Universitas Negeri Surabaya.

Indahningrum, RP \& Handayani, R 2009, Pengaruh kepemilikan manajerial, kepemilikan institusional, dividen, pertumbuhan perusahaan, free cash flow dan profitabilitas terhadap kebijakan hutang perusahaan, Jurnal Bisnis dan Akuntansi, vol.11, no.3, Desember 2009, hlm.189-207.

Jabid, AW. 2009. Kebijakan Dividend Dan Struktur Kepemilikan Terhadap Kebijakan Hutang: Sebuah Perspektif Agency Theory.

Mahendra, Alfredo Dj, Artini, Luh Gede Sri dan Suarjaya, A.A Gede.2012. Pengaruh Kinerja Keuangan terhadap Nilai Perusahaan Pada Perusahaan Manufaktur di Bursa Efek Indonesia. Universitas Udayana Denpasar. Jurnal Manajemen, Strategi Bisnis, dan Kewirausahaan. Vol. 6 (2).

Mamduh, Hanafi. 2004. Manajemen Keuangan. Yogyakarta: BPFE.

Margaretha, F. 2014. Determinants of Debt Policy in Indonesia's Public 
Company. Journal of Business and Economic, 3(2), 10-16.

Mardiyati, Umi. 2016. Pengaruh Kebijakan Deviden, Kebijakan Hutang dan Profitabilitas terhadap Nilai Perusahaan Manufaktur yang Terdaftar di BEI Periode 2005-2010. Jurnal Riset Manajemen Sains Indonesia (JRMSI) Vol.3, No.1.

Milanto, D. 2012, Analisis FaktorFaktor yang Mempengaruhi Kebijakan Hutang, Dinamika Manajemen Vol. 2 (3): 97-112.

Murtiningtyas, Andhika Ivona. 2012. Pengaruh Kebijakan Deviden, Kepemilikan Manajerial, Kepemilikan Institusional, Profitabilitas, dan Resiko Bisnis Terhadap Kebijakan Hutang. Accounting AnalysisJournal.AAJ Volume 1 No.2 Th.2012.

Murni, S. dan Adriana. 2007. Pengaruh Insider Ownership, institutional Investor, Dividend Payments, dan Firm growth terhadap kebijakan hutang perusahaan (studi kasus pada perusahaan manufaktur yang terdaftar di bursa efek Jakarta). Jurnal akuntansi dan bisnis, Vol. 7.No. 1, hlm 15-24.

Riyanto, Bambang. 2011. Dasar-dasar Pembelanjaan Perusahaan. Yogyakarta : BPFE.
Steven \& Lina 2011, Faktor-faktor yang mempengaruhi kebijakan hutang perusahaan manufaktur.Jurnal Bisnis dan Akuntansi. vol.13, no.3, Desember 2011, hlm.163-181.

Susanto, Yulius Kurnia. 2011. Kepemilikan Saham, Kebijakan Dividen, Karakteristik Perusahaan, Risiko Sistimatik, Set Peluang Investasi dan Kebijakan Hutang. Jurnal Bisnis dan Akuntansi. 13 (3), 195-210.

Sutrisno. 2001. Manajemen Keuangan Teori, Konsep, dan Aplikasi. Yogyakarta : EKONISIA.

Sartono, R A, dan Prasetyanta, A, 2005.Pengaruh Perubahan Dividen terhadap Profitabilitas Perusahaan Pada Masa yang Akan Datang", Media Ekonomi dan Bisnis Vol.XVII No.2 Desember, p.20-33.

Yeniatie dan Nicken Destriana.(2010). Faktor-Faktor Yang Mempengaruhi Kebijakan Hutang Pada Perusahaan Non Keuangan Yang Terdaftar di Bursa Efek Indonesia.Jurnal Bisnis dan Akutansi. Volume 12 Nomor 1 halaman 1-16. 